Tumou Tou, Volume VII, Nomor 2:91-111

ISSN 2355-3308 (Cetak), ISSN 2745-9527 (Online)

\title{
IMPLEMENTASI LIMA HARI SEKOLAH DI SMP KATOLIK THEODORUS KOTAMOBAGU DALAM MENGHADAPI PERKEMBANGAN ERA GLOBALISASI
}

\author{
Agus Marulitua Marpaung \\ agus.marpaung@iakn-manado.ac.id \\ Dosen Institut Agama Kristen Negeri Manado \\ Erwin Sianturi \\ esianturi@iakn-manado.ac.id \\ Dosen Institut Agama Kristen Negeri Manado \\ Herdy Laumba \\ herdylaumba@gmail.com \\ Mahasiswa Magister Pascasarjana Institut Agama Kristen Negeri Manado \\ Diterima 9 Maret 2020 \\ Disetujui 1 April 2020
}

\begin{abstract}
Abstrak
Sekolah sebagai wadah pendidikan perlu melakukan optimalisasi sehingga dapat berperan dalam mempersiapkan generasi dalam menghadapi tantangan era globalisasi masa kini. Pemerintah Republik Indonesia melalui Kementerian Pendidikan dan Kebudayaan mengeluarkan Peraturan Menteri Nomor 23 Tahun 2017 tentang lima Hari Sekolah dalam seminggu. Ini merupakan upaya pemerintah untuk meningkatkan peran sekolah dalam penguatan karakter peserta didik sehingga mampu menghadapi perkembangan globalisasi. Namun peraturan ini ternyata ditanggapi pro dan kontra dalam lingkungan pendidikan baik dari pihak penyelenggara sekolah maupun peserta didik dan orangtua. Penelitian ini menggunakan metode kuantitatif dilakukan dengan cara observasi, angket dan penelitian dokumen di SMP Katolik Theodorus Kotamobagu, Sulawesi Utara guna mengetahui Optimalisasi dan dampak kebijakan lima hari sekolah. Hasil dari penelitian menunjukan bahwa telah terjadi perubahan meningkat dari beberapa variable seperti semangat belajar, daya tangkap siswa, gaya mengajar guru, kemauan untuk belajar, dan keaktifan siswa dikelas. Kemudian peran para stakeholder sekolah juga mengalami perkembangan yang signifikan seperti Kepala Sekolah, Guru, Staf kepegawaian, serta orang tua siswa. Maka berdasarkan hasil penelitian ini kebijakan menerapkan lima hari sekolah dalam seinggu mampu meningkatkan optimalisasi fungsi sekolah yang memberikan dampak yang positif terhadap siswa dan stakeholder sekolah.
\end{abstract}

Kata kunci: Kebijakan lima hari sekolah, Implementasi, Peran, Globalisasi, Sekolah 


\section{PENDAHULUAN}

\section{Latar Belakang Masalah}

Di zaman yang disebut oleh generasi saat ini "zaman now" merupakan zaman yang berbasis tehnologi. Hampir semua layanan yang berhubungan dengan aktivitas hari demi hari menggunakan Internet. Data dari Asosiasi Penyelenggara Jasa Internet Indonesia (APJII) menunjukkan bahwa Populasi Penduduk Indonesia pada tahun 2017 mencapai 262 juta orang, lebih dari 50\% atau sekitar 143 Juta orang adalah pengguna internet. ${ }^{1}$ Media sosial merupakan salah satu yang paling banyak diakses karena mampu menghubung kita dengan ribuan bahkan jutaan orang di dunia. Hasil Riset dari We are social dan Hootsuite menyatakan bahwa pada tahun 2017 Indonesia merupakan negara peringkat ke empat dunia sebagai pengguna Facebook teraktif di dunia setelah USA, India dan Brazil dengan jumlah sebanyak 111 juta pengguna. $^{2}$ Ditambah lagi dengan Game Online, Search Engine, messenger, youtube, blog dan bisnis Online. Begitu banyak

\footnotetext{
${ }^{1}$ Kompas.com, 22 Februari 2018 pukul 16.45

${ }^{2}$ Liputan6 news tanggal 21 April 2017 pukul 06.30
}

layanan internet yang akhirnya waktu banyak digunakan untuk penggunaan internet. Dengan demikian zaman ini mendorong dan bahkan memaksa manusia untuk memiliki gaya kehidupan yang mengikuti perkembangan tehnologi masa kini, dimana saat tidak mau mengikuti perkembangan tersebut akan menjadi ketinggalan zaman.

Di satu sisi perkembangan zaman ini membuat segala sesuatu menjadi lebih mudah, cepat dan berkualitas. Namun di sisi lain perkembangan zaman ini juga menggiring kita untuk mulai meninggalkan kebiasaan baik pada zaman sebelumnya seperti interaksi langsung dengan keluarga, teman dan lingkungan, Perubahan perilaku yang lebih memilih untuk hidup dalam dunia maya dibanding dengan kehidupan nyata. Waktu digunakan lebih banyak pada penggunaan internet dibandingkan dengan bersosialisasi dengan kehidupan yang nyata.

Hal ini memberikan pengaruh yang besar bagi dunia pendidikan dimana peserta didik yang merupakan generasi muda masa kini ada dalam perkembangan era globalisasi tersebut. 
Mampukan Pendidikan Indonesia mengantisipasi peserta didik dalam menghadapi tantangan perkembangan era globalisasi ini. Sekolah sebagai wadah pendidikan perlu melakukan optimalisasi sehingga dapat berperan dalam mempersiapkan generasi dalam menghadapi tantangan era globalisasi masa kini. Pemerintah Republik Indonesia melalui Kementerian Pendidikan dan Kebudayaan mengeluarkan Peraturan Menteri Nomor 23 Tahun 2017 tentang Hari Sekolah dilaksanakan 8 (delapan) jam dalam 1 (satu) hari atau 40 (empat puluh) jam selama 5 (lima) hari dalam 1 (satu) minggu. ${ }^{3}$ Ini merupakan upaya pemerintah untuk meningkatkan peran sekolah dalam penguatan karakter peserta didik sehingga mampu menghadapi perkembangan globalisasi. Namun peraturan ini ternyata ditanggapi pro dan kontra dalam lingkungan pendidikan baik dari pihak penyelenggara sekolah maupun peserta didik dan orangtua.

SMP Katolik Theodorus Kotambagu adalah salah satu sekolah yang sudah menerapkan lima hari

3 Kementerian Pendidikan dan Kebudayaan RI, PERMENDIKBUD No. 23 Tahun 2017 tentang Hari Sekolah pasal 2 ayat 1 sekolah sesuai dengan Peraturan Menteri Pendidikan dan Kebudayaan. Dalam observasi awal peneliti mendapat informasi bahwa sekolah ini merupakan sekolah yang berbasis agama namun memiliki siswa dari berbagai agama salah satu alumninya adalah Ibu Walikota Kota Kotamobagu saat ini yang beragama Islam dan sekolah ini juga memiliki banyak prestasi akademik maupun non akademik. Perubahan hari sekolah tentunya memberi dampak bagi kelangsungan proses kegiatan belajarmengajar di sekolah ini dalam rangka meningkatkan peran sekolah mempersiapkan peserta didik menghadapi era globalisasi.

Berdasarkan fenomena tersebut maka penelitian ini ingin menemukan sejauh mana optimalisasi peran sekolah dalam mengimplementasikan pelaksanaan lima hari sekolah di SMP Katolik Theodorus Kotamobagu, dan bagaimana dampaknya bagi peserta didik.

\section{Kajian Literatur}

Hasil Penelitian sebelumnya yang relevan dengan penelitian ini adalah penelitian yang dilakukan Nur Fitasari tahun 2017 dengan judul Persepsi Warga Sekolah Tentang 
Penerapan Peraturan 5 Hari Kerja Di SMK Negeri 1 Cilacap Jawa Tengah. Universitas Negeri Yogyakarta. Penelitian tersebut mencoba menjawab tiga persoalan yang ditemukan yaitu 1) Persepsi guru tentang penerapan peraturan 5 hari kerja dengan persentase, 2) Persepsi karyawan tentang penerapan peraturan 5 hari kerja dengan persentase, 3) Persepsi siswa tentang penerapan peraturan 5 hari belajar dengan persentase.

Penelitian ini memiliki kesamaan dengan penelitian yang akan diteliti oleh peneliti dalam hal mengkaji Peraturan Menteri Pendidikan dan Kebudayaan No.23 Tahun 2017 tentang Hari Sekolah. Namun yang menjadi perbedaannya adalah penelitian yang akan dilaksanakan bukan hanya mengkaji dari sisi persepsi guru, siswa dan karyawan dalam lingkungan sekolah tetapi juga mengkaji Dampak implementasi Lima Hari sekolah dalam mengoptimalisasi peran sekolah dalam mempersiapkan peserta didik menghadapi perkembangan era globalisasi.

\section{KAJIAN TEORI}

\section{Optimalisasi Peran Sekolah}

Berdasarkan arti Kamus Besar
Bahasa Indonesia kata optimalisasi dan sekolah maka Optimalisasi Peran Sekolah merupakan suatu upaya yang terbaik yang dilakukan oleh sekolah dalam menjalankan proses pembelajaran. Muhammad Surya mendefinisikan Kegiatan belajarmengajar atau pembelajaran ialah suatu proses yang dilakukan oleh individu untuk memperoleh suatu perubahan perilaku yang baru secara keseluruhan, sebagai hasil dari pengalaman individu itu sendiri dalam interaksi dengan lingkungannya. ${ }^{4}$ Jadi sekolah merupakan wadah pendidikan formal yang mampu menghasilkan perubahan perilaku bagi peserta didik saat berinteraksi dengan berbagai hal dalam lingkungannya. Dengan kata lain bahwa sekolah sangat berperan untuk mencapai tujuan pendidikan. Yusri Panggabean dkk menyampaikan tujuan pendidikan ada tiga, yaitu: Pertama, untuk membentuk manusia yang mampu melakukan hal-hal baru, bukan hanya mengulang apa yang telah dilakukan oleh generasi sebelumnya. Kedua, membentuk pikiran (mind) yang dapat berpikir kritis. Dan terlebih Ketiga, suka

4 Muhammad Surya, Psikologi
$\begin{aligned} & \text { Pembelajaran dan Pengajaran } \\ & \text { Pustaka Bani Quraisy,2004). }\end{aligned}$


membuktikan sesuatu (verify), tidak menerima saja apa yang ditawarkan kepadanya. ${ }^{5}$ Ketiga tujuan pendidikan ini menunjukkan betapa besarnya peran sekolah ditambah lagi tantangan yang besar dari perkembangan era globalisasi masa kini yang banyak mempengaruhi gaya hidup generasi muda yang merupakan peserta didik dalam dunia pendidikan.

Para penyelenggara pendidikan tidak boleh memandang sebelah mata akan hal tersebut. Karena sekolah menjadi ujung tombak yang diharapkan dapat mempersiapkan peserta didik dalam menghadapi perkembangan era globalisasi. Dalam rangka optimalisasi peran sekolah, pelu diketahui beberapa aspek penting yang mendukung proses pembelajaran di sekolah. B.S.Sidjabat menjelaskan sejumlah aspek yang menunjang keberhasilan pendidikan di sekolah meliputi: 1)Aspek manusiawi, yaitu guru dan murid, 2) Aspek material yaitu kurikulum, silabus, rencana pembelajaran, bahan pelajaran dan sumber pelajaran, 3) Aspek fasilitas yaitu ruangan kelas, alat tulis, media belajar, dan 4) Aspek prosedur yaitu

${ }^{5}$ Yusri Panggabean at al, Strategi, Model dan Evaluasi Pembelajaran ( Bandung: Bina Media Informasi, 2008), 70. jadwal kegiatan, strategi dan metode, teknik penyampaian informasi dan interaksi. ${ }^{6}$

Dalam mengoptimalkan peran sekolah sangat dibutuhkan kualitas guru yang berkompeten. Sardiman A. M. menjelaskan tentang Guru yang kompeten adalah guru yang mampu mengelola program belajar-mengajar. Mengelola di sini memiliki arti yang luas yang menyangkut bagaimana seorang guru mampu menguasai keterampilan dasar mengajar, seperti membuka dan menutup pelajaran, menjelaskan, menvariasi media, bertanya, memberi penguatan, dan sebagainya, juga bagaimana guru menerapkan strategi, teori belajar dan pembelajaran, dan melaksanakan pembelajaran yang kondusif. ${ }^{7}$ Colin Marsh menambahkan dengan menyatakan bahwa "Guru harus memiliki kompetensi mengajar, memotivasi peserta didik, membuat model instruksional, mengelola kelas, berkomunikasi, merencanakan

6 B.S.Sidjabat, Mengajar Secara Profesional (Bandung: Kalam Hidup, 1993), 266.

7 Sardiman, A. M., Interaksi dan motivasi belajar-mengajar (Jakarta: Rajawali.,2004), 165. 
pembelajaran, dan mengevaluasi. Semua kompetensi tersebut mendukung keberhasilan guru dalam mengajar."8 Berdasarkan pendapat Sardiman dan Colin Marsh ini dapat disimpulkan bahwa peran guru begitu sentral dalam mengelola proses pembelajaran, dan peran tersebut sangat berhubungan dengan semua aspek pendidikan baik aspek manusiawi, aspek fasilitas dan aspek prosedur.

Aktivitas yang berjalan di sekolah merupakan sebuah ruang terjadinya proses interaksi belajar mengajar antara guru dan murid. Segala aktivitas yang berlangsung di sekolah merupakan tanggungjawab guru dalam menjalankan tugasnya sebagai tenaga pendidik. Sedangkan peran sekolah adalah mengelola seluruh aspek pendidikan dengan cara yang terbaik agar dapat memberikan suasana pembelajaran yang terbaik yaitu pembelajaran yang efektif, komunikatif dan inovatif. Pemerintah RI melalui Kementerian Pendidikan dan kebudayaan membuat sebuah kebijakan sebagai upaya terobosan untuk mengoptimalisasi peran sekolah dengan

\section{Colin Marsh., Handbook for} Beginning Teachers (Sydney : A.W Longman Australia Pry Limited,1996), 10. mengeluarkan Peraturan Menteri Pendidikan dan Kebudayaan No.23 Tahun 2017 tentang kebijakan lima hari sekolah.

Upaya optimalisasi peran sekolah yang dilakukan oleh pemerintah adalah dengan memberlakukan Hari Sekolah dilaksanakan 8 (delapan) jam dalam 1 (satu) hari atau 40 (empat puluh) jam selama 5 (lima) hari dalam 1 (satu) minggu. Dengan adanya peraturan ini terjadi perubahan jumlah hari sekolah yaitu dari 6 (enam) Senin sampai Sabtu menjadi 5 (hari) Senin sampai Jumat dengan jumlah jam yang sama yaitu 40 jam dalam seminggu. Melalui peraturan ini diharapkan intensitas pertemuan Guru dengan peserta didik sebagai aspek manusia dalam pendidikan semakin tinggi dan proses pembelajaran memberikan dampak yang lebih baik.

Adapun kegiatan yang dilakukan selama 8 (delapan) jam sehari tersebut adalah bagi guru wajib melakukan tanggung jawab mereka yaitu melaksanakan beban kerja guru yang terdiri dari :

a. Merencanakan pembelajaran atau pembimbingan; 
b. Melaksanakan pembelajaran atau pembimbingan;

c. Menilai hasil pembelajaran atau pembimbingan;

d. Mmembimbing dan melatih Peserta Didik; dan

e. Melaksanakan tugas tambahan yang melekat pada pelaksanaan kegiatan pokok sesuai dengan beban kerja Guru.

Sedangkan kegiatan peserta didik adalah melaksanakan tiga kegiatan pokok pendidikan, yaitu

a. Intrakurikuler yaitu kegiatan pemenuhan kurikulum dengan melaksanakan proses pembelajaran secara formal di dalam kelas sesuai dengan jadwal yang telah ditentukan.

b. Kokurikuler merupakan kegiatan yang dilaksanakan untuk penguatan atau pendalaman kompetensi dasar atau indikator pada mata pelajaran/bidang sesuai dengan kurikulum.

c. Ekstrakurikuler merupakan kegiatan di bawah bimbingan dan pengawasan
Sekolah meliputi kegiatan pengayaan mata pelajaran, kegiatan ilmiah, pembimbingan seni dan budaya, dan/atau bentuk kegiatan lain untuk penguatan karakter Peserta Didik. yang bertujuan untuk mengembangkan potensi, bakat, minat, kemampuan, kepribadian, kerjasama, dan kemandirian Peserta Didik secara optimal untuk mendukung pencapaian tujuan pendidikan. Kegiatan ektrakurikuler termasuk kegiatan krida, karya ilmiah, latihan olah-bakat/olahminat, dan keagamaan meliputi madrasah diniyah, pesantren kilat, ceramah keagamaan, katekisasi, retreat, baca tulis Al Quran dan kitab suci lainnya yang dapat dilakukan di dalam maupun lingkungan sekolah sesuai dengan kesepakatan sekolah dengan pihak terkait yang menunjang kegiatan ekstrakurikuler. 


\section{Optimalisasi peran sekolah} terjadi ketika seluruh aspek pendidikan dalam sekolah bekerja dengan baik. Dimana guru melaksanakan tanggung jawabnya sesuai dengan beban kerja guru demikian juga peserta didik melaksanakan kegiatan di sekolah dengan kegiatan yang bervariasi maka akan meningkatkan kualitas pendidikan.

\section{Fenomena Pendidikan Era}

\section{Globalisasi}

Era globalisasi secara wujudnya sudah ada sejak jaman Romawi kuno, atau tepatnya sejak kerajaan Romawi menjajah bangsa Yunani ${ }^{9}$. Namun pada saat itu belum mengenal istilah globalisasi melainkan Osman menyebutnya adalah "Globalization was reality without name ${ }^{\prime 10}$. Imperialisasi atau penjajahan terhadap sebuah negara dianggap oleh Mars secara tidak langsung menghasilkan proses globalisasi. Dimana negara yang berkuasa akan mengatur negara-negara

9 Mars, G. 2001. Workplace Sabotage. The International Library of Criminology. http://repository.radenintan.ac.id.

${ }^{10}$ Osman, B. 2008. Pengaruh Globalisasi Terhadap Peradaban. Jurnal Peradaban, 1. ISSN 1985-6296. jajahannya dengan satu sistem pemerintahan yang mereka miliki. Seperti sistem ekonomi, bahasa, kepercayaan, budaya, pengetahuan, informasi, politik, dan teknologi. Pengaturan satu sistem kepada beberapa negara jajahan menurut Mars merupakan proses "globalisasi tanpa nama".

Istilah era globalisasi itu sendiri baru dikenal pada abad akhir 20 hingga abad 21. Dimana seiring dengan perkembangan teknologi informasi yang merambat diseluruh dunia ${ }^{11}$. Namun mengapa demikian, apa hubungannya istilah era globalisasi dikaitkan dengan perkembangan teknologi informasi? Apabila dilihat dari terminologinya istilah era globalisasi terdiri dari dua kata, yaitu era dan globalisasi. Era berarti tarikh masa, zaman; sedangkan globalisasi berarti proses mengglobal, proses membulat, proses mendunia ${ }^{12}$. Seirama dengan pendapat diatas, Scholte menyebutkan bahwa globalisasi menciptakan adanya Universalisasi atau

11 Hamdani. 2015. Globaslisasi Media dan penyerapan budaya asing, analisasi pada pengaruh budaya populer Korea dikalanagn remaja kota Banda Aceh. Jurnal Avant Garde, vol 3, No.1.Universitas Syiah Kuala. Aceh.

12 Jurnal Pelita Jaman,Volume 8 No.2, 1993. Alkitab.Sabda.Org 
Westernisasi yaitu penyebaran budaya dan cara berpikir suatu tempat yang memiliki pengaruh yang kuat secara global $^{13}$. Sedangkan menurut Waters globalisasi merupakan sebuah proses sosial, dimana batas geografis tidak penting terhadap kondisi sosial budaya, yang akhirnya menjelma ke dalam kesadaran seseorang ${ }^{14}$.

Sehingga berdasarkan ide-ide pemahaman globalisasi diatas dapat dipahami bahwa era globalisasi merupakan dimana manusia berada di dalam masa yang mampu menghubungkan satu dengan yang lain tanpa ada batas-batas jarak, budaya, dan teritorial kenegaraan yang menyentuh berbagai aspek-aspek manusia bahkan dalam tatanan subtansi yang lebih luas. Relasi sosial lintas teritorial manusia menunjukkan adanya relasi komunikasi yang dibangun dengan menggunakan teknologi komunikasi yang mampu menghubungkan manusia dengan manusia lainnya yang dapat diakses secara massal. Maka dapat dipahami penyebaran globalisasi pada masa

\footnotetext{
13 Scholte, J.A. 2005. Globalization; A Critical Indtroduction $2^{\text {nd }}$. http://repository.radenintan.ac.id.

14 Waters, M. 1995. Globalization. $2^{\text {nd }}$ Edition. Taylor and Francais Group. London.
}

sekarang seiring dengan perkembangan tehnologi informasi massal seperti Tv, maupun internet. Penyebaran globalisasi dianggap memiliki dampak baik dan buruk. Sebagian pihak menganggap globalisasi memberikan mereka akses untuk mengenal dunia secara cepat dan menghubungkan mereka dengan orangorang dari berbagai dunia. Sedangkan dari sebagian kelompok yang lain menganggap bawah globalisasi menimbulkan dampak yang buruk sebab akan menimbulkan bentuk imperialisme baru. Menurut Tomlinson, globalisasi akan menciptakan kebudayaan yang homogen, penyeragaman budaya ${ }^{15}$. Akan ada kebudayaan yang harus kalah terhadap budaya yang kuat. Bentuk ini yang disebutkan imperialisasi budaya, penjajahan melalui kebudayaan.

Selain itu perkembangan era globalisasi juga dapat menggiring perubahan perilaku masyarakat dengan melihat, dan meniru informasiinformasi yang mereka terima dari luar. Apalagi perkembangan era globalisasi dan tehnologi informasi pada saat ini sudah dirasakan oleh semua lapisan masyarakat, baik di kota maupun di

15 Tomlinson. 1999. Dalam Hamdani M. Syah Jurnal Avant Garde, vol 3, No.1.Universitas Syiah Kuala. Aceh. 
desa. Hal tersebut disebabkan dari perkembangan tehnologi informasi yang menyediakan akses dan perangkatnya seperti handphone, dan biaya internet yang bisa diperoleh dengan harga yang terjangkau.

Kemajuan ilmu pengetahuan dan tehnologi yang disertai dengan semakin kencangnya arus globalisasi dunia membawa dampak tersendiri bagi dunia pendidikan. Bahkan tehnologi informasi menjadi salah satu produk globalisasi. Banyak sekolah di Indonesia dalam beberapa tahun belakangan ini mulai melakukan globalisasi dalam sistem pendidikan internal sekolah. Hal ini terlihat pada sekolah - sekolah yang dikenal dengan billingual school, dengan diterapkannya bahasa asing seperti bahasa Inggris dan bahasa Mandarin sebagai mata ajar wajib sekolah, apalagi sekolah-sekolah internasional juga semakin ramai bermunculan demi merespon arus globalisasi dunia. Dan tidak jarang juga beberapa sekolah khususnya swasta sudah mengadopsi kurikulum luar negeri untuk diterapkan disekolah, dengan harapan menghasilkan para alumnus yang berkualitas dan mampu bersaing.
Penggunaan sistem teknologi dalam dunia pendidikan memang sudah menjadi kebutuhan, hal tersebut dapat dilihat dari dukungan dan program Kementerian Pendidikan dan Kebudayaan Republik Indonesia untuk mengembangkan kurikulum baru dan sistem online serta mengembangkan pendidikan menuju Indonesia Kreatif tahun $2045^{16}$. Adaptasi dilakukan untuk mencapai kesesuaian konsep dengan kapasitas peserta didik dan kompetensi pendidik dan tenaga kependidikannya supaya memiliki kesinergisan.

Ada dua dampak perkembangan era globalisasi didalam sekolah dampak positif dan negatif. Dampak positif dalam era globalisasi adalah kesadaran untuk meningkatkan kualitas pengajar dari yang metode klasik dengan metode modern ${ }^{17}$. Apabila dulu, guru menulis dengan sebatang kapur, sesekali membuat gambar sederhana atau menggunakan suara-suara dan sarana sederhana lainnya untuk mengkomunikasikan pengetahuan dan informasi, sekarang pengajaran harus

\footnotetext{
${ }^{16}$ Kuntari Eri Murti, Artikel Kurikulum pendidikan 2013

17 I Putu Khirsna Balarama Dasa. Pengaruh Globalisasi Terhadap Dunia Pendidikan. Bali. 2015.
} 
ditingkatakan dengan pengajaran berbasis teknologi baru seperti internet dan computer. Media pengajaran sudah menggunakan komputer atau pun smartphone, bahkan dalam menggumpulkan tugas sudah menggunakan system email.

Sedangkan dampak negatif perkembangan globalisasi di sekolah menurut John Micklethwait salahsatunya adalah meningkatnya kepentingan bisnis sekolah ${ }^{18}$. Banyak sekolah-sekolah didirikan serta merta hanya untuk bisnis semata bukan untuk meningkatkan pendidikan.

Secara bahasa peserta didik adalah orang yang sedang berada pada fase pertumbuhan dan perkembangan baik secara fisik maupun psikis, pertumbuhan dan perkembangan merupakan ciri dari seseorang peserta didik yang perlu bimbingan dari seorang pendidik ${ }^{19}$. Pada fase tersebut kemampuan rasa ingin tahu begitu kuat, apalagi dalam perkembangan era globalisasi ini, dimana segala informasi

18 John Micklethwait dalam I Ketut Sudarsana, Pengaruh Globalisasi Terhadap Dunia Pendidikan.2015, 166

19 Sekretaris Negara Republik Indonesia, UU RI No:20 Tahun 2003, Tentang Sistem Pendidikan Nasional. dapat mudah diperoleh melalui akses internet.

Perkembangan era globalisasi direspon cepat oleh peserta didik sekolah. Informasi-informasi begitu cepat mereka peroleh dari perangkatperangkat elektronik yang miliki. Perkembangan era globalisasi membuat para peserta didik melek teknologi, maksudnya adalah generasi-generasi ini sangat terampil dalam penggunaan sarana-sarana teknologi. Bahkan aktivitas mereka sehari-hari dapat dikatakan tidak lepas dari perangkat teknologi, seperti smartphone, laptop, internet, dan sebagianya. Perangkatperangkat tersebut sudah menjadi teman sehari-hari bagi mereka. Keterampilan menggunakan teknologi digital membantu meningkatkan life skill peserta didik didalam kelas maupun diluar kelas. Misalnya dalam mencari literasi pelajaran tidak perlu harus ke perpustakaan, kemudian mengurus keperluan administrasi, berkomunikasi dan berkoordinasi sesama peserta didik semuanya akan semakin lebih mudah dan cepat.

Namun dalam perkembangan teknologi apabila tidak dikelola atau tidak diawasi akan akan malah merusak 
mental peserta didik. Salah satu dampak negatif dalam era globalisasi ini adalah bebasnya akses memperoleh informasi melalui internet akan memberi kesempatan buat peserta didik membuka situs-situs tidak baik seperti situs porno, terikat penjualan narkoba dan sebagainya. Selain itu maraknya games online misalnya seperti Mobile Legend juga apabila tidak diawasi akan menyebabkan kecanduan dan akan berdampak kepada terganggunya fokus dan waktu belajar peserta-didik.

\section{Dampak Optimalisasi Peran Sekolah}

\section{Bagi Peserta Didik}

Sekolah lima hari ini merupakan bagian dari program penguatan Pendidikan Karakter (PPK) yang di dalamnya ada tiga kegiatan yaitu Intrakurikuler, Kokurikuler dan Ekstrakurikuler. Berdasarkan pemahaman dari kajian diatas maka lima hari sekolah memiliki dampak positif dan dampak negatif. Dampak positif yang dihasilkan pertama, kreatifitas pengajar. Dengan padatnya jam sekolah selama seminggu mendorong para pengajar untuk berinovasi mencipatkan metode pembelajaran yang kreatif, tidak monoton. Kedua, menggiring peserta didik bisa lebih fokus memanfaatkan waktu yang tersedia. Padatnya aktivitas demi aktivitas sekolah meminimalisir peserta didik untuk melakukan perbuatan-perbuatan negatif. Ketiga, dengan diberlakukannya 5 hari sekolah maka akan ada penambahan atau pemadatan jam belajar-mengajar permateri. Sehingga pemadatan tersebut akan membuat pembahasan materi demi materi semakin lebih mendalam.

Kemudian dampak negatif yang ditimbulkan dari implementasi lima hari sekolah adalah, pertama, tingkat stress pendidik dan peserta didik tinggi. Dengan kepadatan jadwal belajarmengajar disekolah akan menimbulkan stress yang tinggi baik dari sisi pendidik maupun peserta didik. Sang pendidik berusaha menciptakan inovasi dan kreatifitas metode pembelajaran secara cepat dan tepat, sedangkan peserta didik harus mampu mengikuti pelajaranpelajaran yang disampaikan dengan transisi waktu yang begitu cepat antara pelajaran satu dengan pelajaran yang lain. Kedua, mempengaruhi daya tahan tubuh, aktivitas sekolah lima hari menuntut kebugaran stamina pendidik dan peserta didik. Tingginya aktivitas 
dengan tuntutan berpikir yang keras membuat tubuh harus bekerja dengan maksimal.

\section{Metode Penelitian}

Metode Penelitian dalam penelitian ini menggunakan Metode Penelitian Kuantitatif dilakukan dengan cara observasi, angket dan penelitian dokumen. Penulis menggunakan penelitian kuantitatif karena dalam penelitian akan diperoleh data-data dalam bentuk angka-angka.

Penelitian ini dilaksanakan pada bulan November 2018 - April 2019 di SMP Katolik Theodorus yang terletak di Jalan Diponegoro Kelurahan Biga Kecamatan Kotamobagu Utara Provinsi Sulawesi Utara. Objeknya adalah Seluruh warga SMP Katolik Theodorus Kotamobagu yaitu siswa, kepala sekolah SMP, guru sebanyak, staf pegawai, dan orang tua siswa. Dalam penelitian lapangan, penulis menggunakan kuesioner (angket) dan wawancara sebagai teknik pengumpulan data. Sedangkan tehnik analisis data menggunakan frekuensi presentase dengan rumus sebagai berikut:

$$
\%=-{ }_{\mathrm{N}} \mathrm{X} 100 \%
$$

Keterangan :

$\%=$ presentase pemilih

$\mathrm{P}=$ jumlah pemilih

$\mathrm{N}=$ jumlah keseluruhan

responden

\section{HASIL DAN PEMBAHASAN}

Cikal bakal berdirinya SMP Katolik Theodorus adalah atas permintaan Bupati Bolaang Mongondow Bapak H. Y. C. Manoppo yang lebih populer dengan nama atau gelar Abo Heni (Keturunan Raja Manoppo) kepada Pastor Paroki Kristus Raja Bolaang Mongondow yaitu Pastor Hubertus Geurst, MSC, supaya di daerah Bolaang Mongondow didirikan SMP Katolik. Menanggapi permintaan tersebut, maka pastor paroki membicarakan dengan tokoh-tokoh umat Katolik saat itu dan membentuk panitia pembangunan gedung sekolah SMP Katolik Theodorus.

Tanggal 17 September 1957 sekolah dibuka secara resmi melakukan operasionalnya dengan Pelaksana Harian sebagai kepala sekolah adalah Bapak P. F Tulusan sebab kepala 
sekolah definitif bapak F. A Kainde (Alm) baru datang bulan oktober 1957, dengan jumlah siswa 62 orang, tenaga/guru pengajar 3 orang, yaitu Bapak P. F. Tulusan, Bapak Y. Wenur (Alm), Bapak F. A. Kainde (Alm). Ruang kelas berjumlah 2 ruang yaitu kelas I A dan kelas I B. Mulai dari pada 1 Agustus 1957 s.d Juli 1959 bapak F. A. Kainde menjabat sebagai kepala sekolah.

Saat ini SMP Katolik Theodorus Kotamobagu terakreditasi $\mathrm{A}^{20}$. Jumlah pengajar 15 orang dengan kualifikasi pendidikan S1/D4 dengan total siswa sebanyak 239 orang dan dilengkapi dengan ruang kelas sejumlah 26 ruangan. Salah satu sekolah yang terkenal dengan memiliki mutu kualitas belajar mengajar yang unggul. SMP Katolik Theodorus memiliki latar belakang pendidikan Katolik namun siswa-siswanya cukup banyak yang beragama Islam dan saling rukun saling membantu serta bertoleransi antar siswa yang beragama lain.

Berdasarkan Pengumpulan data , maka data tentang berbagai

20 Data Pokok Pendidikan Dasar dan Menengah Dirjen Pendidikan Dasar dan Menengah, Kemendikbud. karakteristik responden dalam

penelitian ini dapat dilihat dari tabel dan diagram berikut ini:

Tabel.4.1

Karakteristik responden berdasarkan

Kelas

\begin{tabular}{|c|l|c|c|c|}
\hline No & Kelas & Jumlah & $\begin{array}{c}\text { Jumlah } \\
\text { siswa }\end{array}$ & $\begin{array}{c}\text { Persen } \\
\text { tase }\end{array}$ \\
\hline 1 & VII & 3 & 93 & $38,9 \%$ \\
\hline 2 & VIII & 3 & 80 & $\begin{array}{c}33,47 \\
\%\end{array}$ \\
\hline 3 & IX & 1 & 66 & $\begin{array}{c}27,61 \\
\%\end{array}$ \\
\hline & Jumlah & 10 & 239 & $100 \%$ \\
\hline
\end{tabular}

Tabel diatas menunjukkan bahwa responden yang berjumlah 239 orang terdiri dari 3 (tiga) Tingkatan kelas tingkat SLTP yaitu Kelas VII sebesar $38,9 \%$, Kelas VIII sebesar 22,47 \% dan kelas IX sebesar 27,61\%.

Untuk memaksimalkan proses pembelajaran maka setiap tingkatan kelas didistribusikan dalam beberapa kelas yang tertera dalam table berikut ini.

Tabel.4.2

Distribusi Responden berdasarkan kelas 


\begin{tabular}{|c|l|c|c|}
\hline No & Kelas & $\begin{array}{c}\text { Jumlah } \\
\text { siswa }\end{array}$ & Persentase \\
\hline 1 & VII A & 34 & $14,22 \%$ \\
\hline 2 & VII B & 30 & $12,55 \%$ \\
\hline 3 & VII C & 29 & $12,13 \%$ \\
\hline 4 & VIII A & 28 & $11,71 \%$ \\
\hline 5 & VIII B & 27 & $11,29 \%$ \\
\hline 6 & VIII C & 25 & $10,46 \%$ \\
\hline 7 & IX & 66 & $27,61 \%$ \\
\hline & Jumlah & 239 & $100 \%$ \\
\hline
\end{tabular}

maka berikut adalah rekapitulasi data angket untuk keseluruhan kelas di SMP Katolik Theodorus Kotamobagu tentang Pelaksanaan Lima Hari Sekolah:

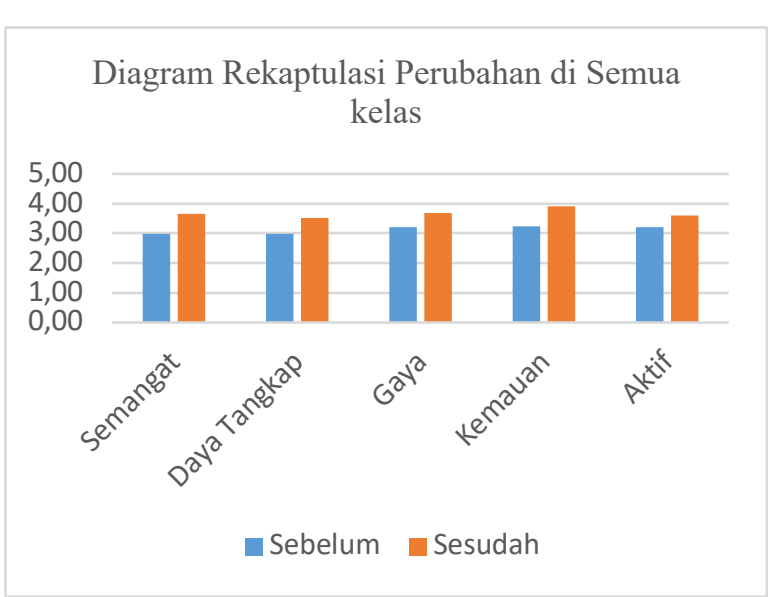

Berdasarkan Data angket yang telah didistribusikan kepada responden ada 2 (dua) bagian besar informasi yang dikumpulkan yaitu:

1. Pendapat siswa tentang Perubahan yang terjadi setelah dilaksanakankan lima hari sekolah yang akan ditampilkan melalui diagram.

2. Pendapat siswa tentang peran dari unsur-unsur yang terkait dalam menunjang proses pembelajaran yaitu: Guru, Orangtua, Kepala sekolah dan Pegawai.

\section{Hasil Temuan Data}

Berdasarkan data angket dari ketiga Tingkatan kelas VII,VIII,dan IX 


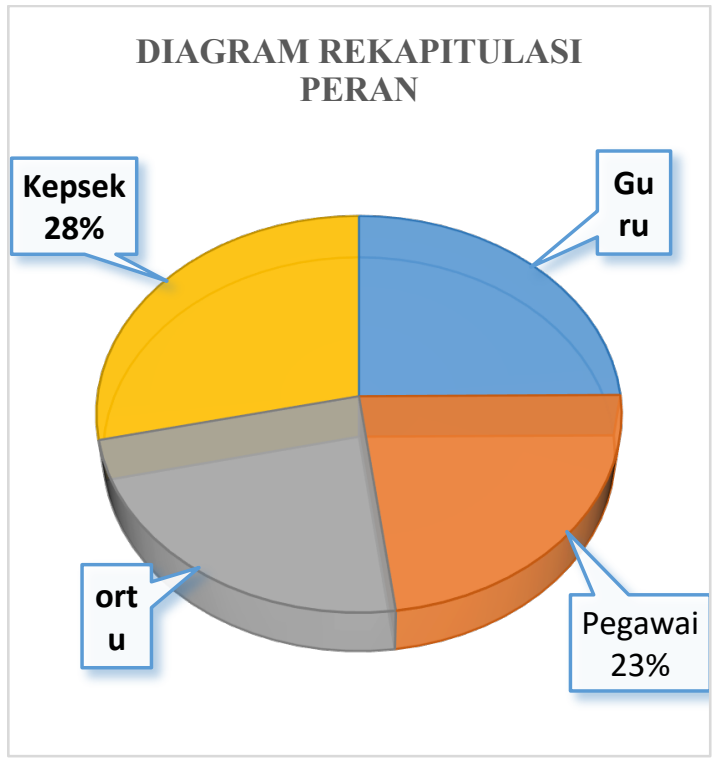

Selanjutnya diagram lingkaran di atas adalah rekapitulasi peran dengan rincian angka; kepala sekolah 29\%, guru $25 \%$, pegawai $23 \%$ dan orang tua $23 \%$. Data yang dipaparkan di atas adalah data yang diperoleh melalui angket dengan responden seluruh siswasiswi SMP Katolik Theodorus Kotamobagu. Selain dengan data yang diperoleh melalui angket yang tersebut di atas, peneliti juga melakukan observasi untuk mendukung atau melengkapi data yang dimaksud.

\section{Pembahasan}

Dari pengamatan yang dilakukan peneliti mengamati bahwa siswa-siswi memiliki keaktifan di dalam kelas. Hal ini terlihat ketika guru bertanya kepada para siswa di akhir penjelasan materi pelajaran atau meminta para siswa untuk memberi tanggapan perihal pelajaran yang baru berlangsung, sebagian besar siswa-siswi langsung mengangkat tangan sebagai respon untuk menanggapi dan atau menjawab pertanyaan dari guru. Siswa-siswi terlihat giat dan semangat mengikuti setiap mata pelajaran. dan guru sebagai tutor tetap menjalankan tugasnya dengan baik sampai akhir. Guru dan siswa sama-sama mengikuti jam pelajaran sampai akhir jam pelajaran yaitu 14.00 WITA.

Kegiatan di sekolah terbilang padat karena selain belajar di kelas ditambah dengan kegiatan ekstrakurikuler. Selain itu terlihat bahwa tidak ada siswa-siswi yang berkeluyuran di lingkungan sekolah saat pelajaran sedang berlangsung. Guruguru mata pelajaran langsung berada di kelas saat bel pergantian jam berbunyi. Jam istirahat pun digunakan sebaik mungkin oleh para siswa. Ketika mengadakan observasi, peneliti mendapati ada beberapa guru yang tidak masuk karena mengikuti kegiatan Olimpiade Guru Nasional (OGN). Apabila ada kelas yang gurunya tidak masuk, sebagai pimpinan kepala 
sekolah masuk di kelas-kelas menggantikan guru yang tidak masuk atau yang sedang ada kegiatan lain.

Siswa-siswi terlihat senang mengikuti arahan dari kepala sekolah. Kemudian setelah selesai pembelajaran di kelas sebagian siswa-siswi masih mengikuti latihan menyanyi lagu Insieme in Devinity. Dalam pelaksanaan pembelajaran guru menggunakan alat peraga misalnya dengan menggunakan metode eksperimen yaitu dengan melukis menggunakan cat air. Metode lain seperti metode yang digunakan pada umumnya seperti diskusi kelompok, cerama, tanya jawab, studi kasus dan metode dialog antara siswa dan guru sebagai proses berpikir sehingga terjadi interaksi dalam kelas.

Semua kegiatan sekolah diikuti dengan baik oleh siswa-siswi SMP Katolik Theodorus Kotamobagu. Siswasiswi terlihat antusias ketika mengikuti semua kegiatan baik di kelas maupun di luar kelas. Siswa-siswi senang dan menikmati jalannya semua kegiatan yang diselenggarakan sekolah. Bukan hanya siswa guru-guru pun memiliki semangat yang sama dalam pelaksanaan pembelajaran di kelas dan di luar kelas.
Jalannya proses belajar tentunya didukung dengan sarana prasasara yang ada di sekolah. Sarana dan prasarana pendukung yang digunakan dalam proses pembelajaran antara lain buku cetak, papan tulis, spidol, penghapus, lapangan olahraga, laboratorium komputer, ruangan audio visual, speaker aktif di tiap ruangan untuk menyampaikan informasi, dan lingkungan sekolah yang aman dan nyaman. Dalam upacara sarana yang digunakan adalah mike dan speker. Kemudian dalam kegiatan Life Skill atau yang dikenal dengan istilah umum Minat dan Bakat siswa-siswi memanfaatkan sarana sekolah seperti alat musik dan sarana olahraga.

Kegiatan belajar mengajar di sekolah termasuk juga kegiatan ekstrakurikuler dapat terlaksana dengan baik karena semua stakeholder sekolah bersinergi termasuk orang tua. Data yang dipaparkan yang diperoleh melalui angket di atas di dukung dengan hasil observasi. Setelah di rekapitulasi diagram perubahan menunjukkan adanya peningkatan yang signifikan. Selaras dengan rekapitulasi perubahan, hasil observasi menunjukkan siswasiswi memiliki kemauan belajar yang 
cukup tinggi dengan angka sebelumnya 3,23 meningkat menjadi 4,23 hal ini terlihat karena peneliti mengamati adanya semangat yang menunjukkan angka sebelumnya 3,27 meningkat menjadi 3,67 dan keaktifan siswa dalam kelas dengan angka 2,84 meningkat menjadi 3,64 dan daya tangkap siswa dari angka 2,86 meningkat menjadi 3,71. Peningkatan kualitas belajar yang dimaksud dipengaruhi oleh gaya mengajar guru yang sebelumnya menunjukkan angka 2,98 meningkat menjadi 3,77 .

Sementara itu diagram peran menunjukkan, kepala sekolah berada pada posisi teratas yakni 29\%. Peneliti telah mengamati bahwa kepalah sekolah memegang peranan yang sangat penting dalam pelaksanaan lima hari sekolah. Kepala sekolah sebagai pimpinan selalu mengawasi akan jalannya proses pembelajaran. Ketika ada guru yang tidak masuk kelas atau sedang dinas luar atau dengan alasan yang lainnya, maka kepalah sekolah masuk di kelas untuk menggantikan guru yang bersangkutan. Peneliti juga mengamati bahwa kedekatan kepala sekolah dengan siswa-siswi juga berpengaruh pada pencapaian perannya sebagai pimpinan.
Kepala sekolah melakukan pendekatan kepada setiap siswa-siswi sebagai bentuk kepeduliannya kepada siswasiswa bukan dengan gaya kepemimpinan yang otoriter. Selain itu hampir setiap nama dari siswa-siswi dihafal oleh kepala sekolah.

Sama halnya dengan guru, guru punya peran tersendiri dalam pelaksanaan pembelajaran. Diagram lingkaran tentang peran menunjukkan guru berada pada posisi kedua dengan angka 25\%. Peneliti mengamati bahwa secara keseluruhan guru-guru yang ada di SMP Katolik Theodorus Kotamobagu memiliki kreatifitas yang cukup tinggi, dan guru-guru sangat profesional dalam melaksanakan tugasnya sebagai pendidik. Misalnya tidak terlambat, berpakaian sesuai aturan, melaksanakan tugas mengajar sesuai dengan jam pelajaran yang sudah ditentukan dan pulang tepat waktu.

Kemudian pegawai menunjukkan angka $23 \%$ juga melaksanakan tugasnya sebagiamana mestinya. Kelancaran dalam proses belajar mengajar di SMP Katolik Theodorus Kotamobagu adalah bukti bahwa tenaga kepegawaian menjalankan tugasnya dengan baik. 
Mulai dari petugas keamanan, staf tata usaha, pegawai perpustakaan sampai petugas kebersihan. Bahkan pegawai perpustakaan juga berperan sebagai pelatih pramuka.

Selanjutnya orang tua. Dari hasil rekapitulasi peran, peran orang tua menunjukkan angka 23\%. Peneliti tidak dapat mengamati secara penuh bagaimana peran orang tua terkait dengan pelaksanaan lima hari sekolah di SMP Katolik Theodorus Kotamobagu karena orang tua secara langsung berperan lebih banyak di rumah. Tetapi sejauh yang dapat diamati bahwa beberapa orang tua membawakan/mengantarkan bekal kepada anak-anak mereka sebelum jam istirahat yang dititipkan kepada petugas piket. Selain itu peneliti juga sempat bertanya kepada seluruh siswa-siswi dalam satu kelas, apa peran orang tua di sekolah terkait dengan pelaksanaan lima hari sekolah? Secara serentak mereka menjawab bahwa adanya penambahan uang jajan.

\section{Kesimpulan}

Berdasarkan rumusan masalah dan tujuan penelitian ini maka dapat ditarik kesimpulan bahwa kemampuan siswa dapat dioptimalkan ketika semua unsur sekolah saling bersinergi dalam menciptakan suasana belajar-mengajar di sekolah yaitu, guru-guru meningkatkan kreatifitas mengajar, staf tata usaha menjalankan tugasnya sebagai tenaga administrasi yang sangat mendukung kelancaran proses belajar mengajar, sekuriti dan tukang kebun yang menjamin keamanan dan kenyamanan lingkungan sekolah serta peran pimpinan yang mengkoordinir semua unsur sekolah yang terkait tersebut. Padatnya jam pelajaran dan sedikitnya jam istrahat menuntut model pembelajaran yang kreatif dan tidak monoton supaya siswa-siswa tidak bosan. Selain itu siswa dan guru juga menjadi terlatih dengan kemampuan mengelolah waktu serta terbiasa akan sistem kerja yang cepat juga kreatif. Produktifitas yang diciptakan oleh guru dan siswa juga menuntut perangkatperangkat sekolah lainnya juga harus menyimbangi kinerja yang baik guna mendukung aktivitas belajar mengajar yang semakin padat. Kemudian kondisi tersebut membuat siswa menuntut kepada orang tua untuk lebih berperan membantu aktifitas belajar mereka di sekolah seperti penambahan uang jajan, 
antar jemput, hingga mengantarkan bekal makanan bagi mereka. Namun hal tersebut harus dijaga supaya konsisten dan peran kepala sekolah menjadi figur yang paling berperan menjaga ritme dan konsistensi aktivitas belajar-mengajar yang telah meningkat. Data dari temuan penelitian terkait dengan pelaksanaan lima hari sekolah memperlihatkan adanya peningkatan aktivitas belajarmengajar karena telah menunjukan perubahan yang signifikan.

\section{Daftar Pustaka}

Dasa, I Putu Khirsna Balarama. Pengaruh Globalisasi Terhadap Dunia Pendidikan. Bali. 2015.

Hamdani., Globalisasi Media dan penyerapan budaya asing, analisasi pada pengaruh budaya populer Korea dikalanagn remaja kota Banda Aceh. Jurnal Avant Garde, vol 3, No.1.Universitas Syiah Kuala. Aceh, 2005

Jurnal Pelita Jaman,Volume 8 No.2, 1993. Alkitab.Sabda.Org

Kementerian Pendidikan dan Kebudayaan RI, PERMENDIKBUD No. 23 Tahun 2017 tentang Hari Sekolah pasal 2 ayat 1

Marsh, Colin., Handbook for Beginning Teachers, Sydney : A.W Longman Australia Pry Limited,1996

Mars, G. Workplace Sabotage. The International Library of Criminology. http://repository.radenintan.ac.id, 2001

Micklethwait, John dalam I Ketut Sudarsana, Pengaruh Globalisasi Terhadap Dunia Pendidika, 2015

Muhammad Surya, Psikologi Pembelajaran dan Pengajaran, Bandung: Pustaka Bani Quraisy,2004

Murti, Kuntari Eri, Artikel Kurikulum pendidikan 2013

Osman, $\quad$ B.,Pengaruh Globalisasi Terhadap Peradaban. Jurnal Peradaban, 2008

Panggabean, Yusri at al, Strategi, Model dan Evaluasi Pembelajaran, Bandung: Bina Media Informasi, 2008

Sardiman, A. M., Interaksi_dan motivasi belajar-mengajar, Jakarta: Rajawali,2004

Sekretaris Negara Republik Indonesia, UU RI No:20 Tahun 2003, Tentang Sistem Pendidikan

Nasional.

Sidjabat, B.S., Mengajar Secara Profesional, Bandung: Kalam Hidup, 1993

Sugiyono, Statistika untuk Penelitian. Bandung: Alfabeta, 1999

Tomlinson. Dalam Hamdani M. Syah Jurnal Avant Garde, vol 3, 1999

Waters, $\quad$ M. 1995. Globalization. $2^{\text {nd }}$ Edition. Taylor and Francais Group. London.

No.1. Universitas Syiah Kuala. Aceh. 
Kompas.com, 22 Februari 2018 pukul 16.45

Liputan6 news tanggal 21 April 2017 pukul 06.30 